\title{
Sequential floods drive 'booms' and wetland persistence in dryland rivers: a synthesis
}

Catherine Leigh ${ }^{A^{*}}$, Fran Sheldon ${ }^{A}$, Richard T. Kingsford ${ }^{B}$ and Angela $H$. Arthington $^{\mathrm{A}}$

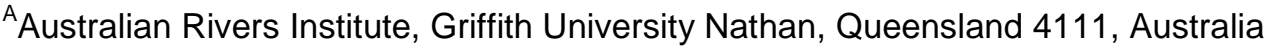

${ }^{B}$ Australian Wetlands and Rivers Centre, University of New South Wales, NSW 2052

*Corresponding Author. Email: c.leigh@griffith.edu.au

\begin{abstract}
Flow is a key driver regulating processes and diversity in river systems across a range of temporal and spatial scales. In dryland rivers, variability in the timing and scale of floods has specific ecological significance, playing a major role in sustaining biotic diversity across the river-floodplain mosaic. However, longitudinal effects of floods are equally important, delivering water progressively downstream through channels and wetland complexes. Interaction among the spatial distribution of these wetlands, their connecting channel and floodplain geomorphology and the temporal variation in flow events not only creates the spatial complexity of wetted habitat in dryland rivers but also determines their temporal persistence. These wetlands act as hydrological 'sponges', absorbing water from upstream and needing to fill before releasing water downstream. Sequential high flow events are therefore essential for the ecological persistence of riverine wetlands and the transmission of flows further downstream through the channel network. These flood sequences maintain aquatic refugia and drive booms in productivity that sustain aquatic and terrestrial biota over large spatial and temporal scales. Disrupting the sequence, due to modified flow regimes and water removal for anthropogenic consumption (e.g. irrigation), significantly reduces the opportunity for wetland replenishment. As a result, the benefits of sequential flooding to the wetland sponges and their biotic communities will be lost.
\end{abstract}

\section{Key words}


Wetlands, hydrological connectivity, floodplain rivers, Cooper Creek, Murray Darling Basin, desert streams, arid-zone rivers, water resource development, boom and bust ecology

\section{Introduction}

Flow is a key driver regulating processes and diversity in river systems across a range of temporal and spatial scales: the "maestro" of river ecology (Walker et al. 1995) (Fig. 1). Magnitude, duration, frequency and seasonality are the broad facets of flow that mediate processes in river systems (Poff et al. 1997; Olden and Poff 2003). In Australian dryland rivers, these facets reflect the most variable flow regimes in the world (Puckridge et al. 1998a), with the El Niño Southern Oscillation (ENSO) contributing significantly to this variability (Simpson et al. 1993; Walker et al. 1995; Chiew et al. 1998). There is now recognition that six facets of flow have ecological relevance to dryland rivers in Australia and perhaps elsewhere (Naiman et al. 2008): magnitude, frequency, timing, duration, variability and rate of change (Fig. 1).

Variability in timing and scale of floods in dryland rivers has specific ecological significance (Walker et al.1995; Puckridge et al. 2000; Sheldon and Thoms 2006). Flow variability is such a strong hydroecological force that it is probably more important in structuring aquatic assemblages than biological factors (like competition among species for food and habitat) or other density-dependent regulatory processes (see Sheldon et al. 2002; Arthington et al. 2005; Poff et al. 2007; Naiman et al. 2008; Larned et al. 2010). Indeed, close association between biotic diversity and flow variability in semi-arid and arid-zone rivers has been observed in systems as far removed as North and South America and central Australia (Stanley et al. 1997; Maltchik and Medeiros 2006, Sheldon et al. 2002). In Australian dryland rivers, climatic and hydrological factors have shaped a suite of species well adapted to the dynamic conditions experienced in these systems - the wide physiological tolerances and flexible life-histories of many fish species, for example, allow for opportunistic breeding and migration to occur across the fluctuating environment (Mallen-Cooper and Stuart 2003; Balcombe et al. 2006; Balcombe and Arthington 2009; Sheldon et al. this issue). the ecology of large rivers (Junk et al. 1989; Tockner et al. 2000). For Australian dryland 
systems, the dynamic variability in water quality (Sheldon and Fellows this issue), assemblage composition (Marshall et al. 2006; Leigh and Sheldon 2009; Arthington et al. this issue) and biogeochemical processes (Burford et al. 2008; Fellows et al. 2009) reflects the dynamic and variable interaction of the river with its floodplain. Indeed, floodplain rivers are characterised by a spatial and temporal complex of habitats that have varying levels of hydrological connectivity, both longitudinal and lateral (Ward et al. 1999; Paillex et al. 2009). Variability in this connectivity, and therefore the spatial and temporal patchiness of the habitat mosaic, is governed by channel and waterhole geomorphology, landscape topology and the nature of flows themselves, whether they be overbank (floods, sensu Junk et al. 1989), absent (dry periods and zero flows) or otherwise (flow pulses, sensu Puckridge et al. 1998a; Bunn et al. 2006) (Fig. 1). Bunn et al. (2006) described the change in productivity and food sources that accompany these events as 'boom, bust and the bits in between' (after Walker et al. 1997). During dry periods, algal production around the edges of floodplain waterholes provides the primary support for higher trophic levels (Bunn et al. 2003; Sheldon et al. this issue). During floods, the floodplain booms with aquatic production, providing a huge food source to aquatic and terrestrial consumers (Balcombe et al. 2005; Bunn et al. 2006). In-channel flows (flow pulses) mark the 'inbetween' phase, when it is unlikely that either source of production is available (Bunn et al. 2006; Fellows et al. 2009). Variation in flow and flood pulse magnitudes also play a key role in sustaining diverse plant communities in these dryland river-floodplains (e.g. Capon 2007).

For large river systems, the longitudinal effects of floods on river function can be just as important as the lateral connectivity, especially in dryland rivers (Hughes 2005; Larned et al. 2010). Although small flow pulses may not penetrate far along the system, they often provide a fundamental 'wetting' role that allows subsequent small or large pulses to travel further and support river production and biodiversity. The role of 'sequential flooding' in driving incredible booms in productivity was first described by Jim Puckridge in the Coongie Lakes wetland complex, Cooper Creek, Lake Eyre Basin. Puckridge et al. (2000) showed that a cluster of five floods, over a four year La Niña period, had cumulative, positive effects on the area inundated and reproductive output of native fish populations. Serial high flow events enable hydrological 'carry-over' effects that ensure the ecological persistence of habitats and assemblages within the dryland river system. 
In this paper we review the spatial and temporal variability in flow in large river systems and summarise its importance in driving assemblage variability through space and time. We suggest how sequences of floods can penetrate differentially through large river networks and provide a template for the incredible booms in production witnessed in these systems. We link the space and time aspects of flooding in large rivers and explore the consequences for regulated river systems when the interaction between space and time dimensions is disrupted.

\section{Flow Variability in Space and Time}

Flow variations occur over a range of temporal scales in rivers, from seconds (rising and falling water levels) to periods greater than 10000 years (incorporating the frequencies of the largest floods and longest dry periods). Walker et al. (1995) recognised three distinct temporal 'scales' of flow, the shortest being the 'flow pulse' (Fig. 2a). The flow pulse represents the annual or seasonal flow event that is important for maintaining ecological processes such as nutrient cycling, breeding and spawning responses, and dispersal. The magnitude of a particular flow event will also have specific physical and biological consequences, with high flows (overbank floods) providing a vector for lateral exchange of materials and energy between channel and floodplain environments. These lateral exchanges are of particular significance in dryland river systems (Walker et al. 1995; Hughes 2005).

Flow pulses that occur at different frequencies also serve different biological and biogeochemical functions. Relatively frequent flows (e.g. one year return) may be important for migration and connectivity (Poff et al. 1997), for sustaining diverse and productive propagule banks (Capon 2007; Jenkins and Boulton 2007) and for regular nutrient releases and inputs of materials from the terrestrial environment (Valett et al. 2005). Less frequent floods may be important as ecological reset phenomena and for the dispersal of invertebrates (Malmqvist 2002). Large floods (large flow pulses) tend to be even less frequent (decadal to century-scale intervals; Naiman et al. 2008). They can cover vast areas and provide water to large lake systems that are dry most of the time (e.g. Lake Eyre in the Australian arid interior). These large events are important to floodplain environments for disturbing and resetting the aquatic environment (Stanley et al. 1997; Pettit and Naiman 2005); stimulating successional processes (Fisher et al. 1982) and providing water to floodplain vegetation (Capon 2005); connecting distant waterholes; 
flushing wetlands; flooding the broad range of habitats required for waterbird breeding and recruitment (Kingsford et al. this issue); transferring sediments and other materials like nutrients between channel and floodplain environments (Junk et al. 1989; Walker et al. 1995; Jacobson et al. 2000); and for allowing channel species to access floodplain environments (Tockner et al. 1999; Junk and Wantzen 2003; Thoms 2003). Indeed, floodplain rivers typically show strong relationships between the magnitude of the annual flood pulse, floodplain area inundated and fish production in the same or subsequent years (Bayley 1991; Arthington et al. 2005; Welcomme et al. 2006).

From a biological perspective, the duration of an individual flood determines how well aquatic organisms can exploit the channel network (longitudinal connection) and lateral floodplain resources. In the lower reaches of many (especially unregulated) river systems, the duration of overbank flow may be one of the most biologically important hydrological features (Junk et al. 1989). Large floods are particularly important as they can have long durations, which create long breeding seasons and greater opportunities for production, recruitment and growth (Balcombe et al. 2007; Bunn et al. 2006; Puckridge et al. this issue). These long-duration floods also allow for increased levels of floodplain production which, in turn, may be important for community maintenance during periods when flows are contained within channels or waterholes are disconnected (cf. Thoms et al. 2005; Bunn et al., 2006; Noe and Hupp 2007; Gallardo et al 2009; Sheldon et al., this issue). For example, most fish species in Cooper Creek gain energetic subsidies from their time spent foraging on inundated floodplains, where food resources are more diverse and plentiful than in isolated waterholes (Balcombe et al. 2005; Burford et al. 2008). In addition, moderate floods in between these big breeding events may provide 'maintenance' recruitment (Davies et al. 1993; Balcombe and Arthington 2009) and sustain adequate habitat quality, which will indirectly affect the success of breeding events in the future.

Preceding any individual flow pulse, there is a 'flow history' - a sequence of ecologically relevant facets of flow acting on the system over a longer temporal scale (Fig. 2b). Flow history represents the antecedent conditions relating to any one flow pulse or flood, and describes the cycling of moderate floods and dry spells within periods of above or below average flow magnitude. In periods of higher than average flooding, antecedent conditions for any flood event may be important for higher than average recruitment success and species abundance (Puckridge et al. 2000). Comparatively, periods of below average 
flooding or dry periods represent times of population restriction, isolation and local extinction (Arthington et al. this issue). The ecological importance of a given flow event may be related to the length of time since the last event, or the last flow event of the same magnitude or duration. For example, a certain length of time may be required for riparian vegetation to re-establish or for successional stages to be reached in aquatic communities (e.g. Kingsford 2000; Pettit et al. 2001). Low flow and drought periods, and the interval between these periods, are also strong determinants of population and community structure for many plants and animals (e.g. Humphries et al. 1999; Bond et al. 2008).

Like floods, dry periods are natural disturbances in dryland rivers. They also act as reset phenomena for aquatic biota (Stanley et al. 1997; Bond et al. 2008) and can play an important role in redistributing nutrients that have become bound in the tissues of organisms (Burford et al. 2008). During dry periods, dryland rivers may consist of a series of isolated pools or refugia, with the aquatic animals and plants well adapted to these periods exhibiting morphological, physiological and behavioural adaptations (Stanley et al. 1997; Arthington et al. this issue; Sheldon et al. this issue). Indeed, dry spells and low flows serve a number of important ecological functions in dryland rivers. In dry times, refugia provide a diverse range of habitats that allow the persistence of a diversity of assemblages (Dodds et al. 2004; Sheldon et al. this issue), while low channel flows provide short-term connections between otherwise isolated sections of the river network ; toppingup and sustaining permanent waterholes (cf. Lake 1995, 2003; Bunn et al. 2006) and allowing fish redistribution within the channel network.

At even longer time scales, we describe the 'flow regime' (Fig. 2c), covering the long-term cycles of flood and drought (unusually extended dry periods) common to many large river systems and controlled by climatic fluctuations and landscape features. Ecologically relevant features of the flow regime are described in terms of statistical measures, commonly based on mean daily flow records, such as the annual mean, minimum and maximum flow; various percentiles of discharge; low and high flow spell durations, number of zero flow days; and the frequency, timing and variability of these statistics (e.g. Olden and Poff 2003; Kennard et al. 2010). These hydrologic statistics can be used to classify rivers into groups with hydrologically similar flow regimes (e.g. Monk et al. 2007; Leigh and Sheldon 2008; Kennard et al. 2010). In fact, descriptors of long term flow variability show that Australian dryland rivers have the most variable flow regimes for 
rivers of comparable discharge in the world (Finlayson and McMahon 1988; Puckridge et al. 1998a).

\section{Spatial Complexity in Dryland Rivers}

Spatial complexity in dryland rivers is influenced by channel and floodplain geomorphology over the full range of spatial scales such that these systems can display a range of both lotic and lentic habitats, including in-channel waterholes, channel backwaters, floodplain billabongs and wetlands (Knighton and Nanson 1997; Gibling et al. 1998; Ward et al. 1999; Heffernan 2008). At small spatial scales, sediments deposited over geological time can form multi-level floodplains within river channels, which increase the spatial and habitat complexity of the river channel itself (Sheldon and Thoms 2006). Across the river-floodplain and channel network, comparatively deep parts and more permanent sections (waterholes) can serve as refugia for aquatic biota during periods between flow events (Knighton and Nanson 1994; Hamilton et al. 2005; Sheldon et al. this issue). The permanence of these refugia is controlled by the frequency, magnitude and duration of flow events as well as waterhole and channel morphology and evaporative loss (Stanley et al. 1997; Hamilton et al. 2005; Bunn et al. 2006).

In Australia, at large spatial scales (thousands of kilometres), river systems are typified by low gradients, a consequence of the continent's low topography (Bridgewater 1987). This pattern of low relief is characteristic of Australia's large dryland rivers, both arheic and endorheic, and creates the broad floodplains and complex wetlands (both terminal and riverine) found throughout these systems. Within the major river systems of the Lake Eyre Basin (Fig 3), for example, complex riverine wetlands occur on Cooper Creek in the Cooper Channel country downstream of Windorah. In addition, a series of shallow, temporary lowland lakes and channel habitats of varying depths, known as the Coongie Lakes wetlands, are fed intermittently by the Northwest Branch of the Cooper Creek and cover an area of more than $2000 \mathrm{~km}^{2}$ (Puckridge et al. 1998b, Sheldon et al. 2002). Further downstream are the lower Cooper lakes (Kingsford et al. 1999) and, finally, the large terminal inland Lake Eyre (Fig. 3). A similar pattern is evident within the GeorginaDiamantina catchment; the wetland complex of Diamantina Lakes occurs in the middle of the Diamantina River catchment (Fig. 3), while further downstream the river flows through another complex wetland (Goyder Lagoon; Sheldon and Puckridge 1998) before spilling into Warburton Creek and its associated wetlands, terminating at Lake Eyre. Further west, 
the Georgina and Mulligan Rivers flow through the complex wetlands of Eyre Creek, before reaching the Diamantina River (Fig. 3). Interaction among the spatial distribution of these shallow wetlands, their connecting channel and floodplain geomorphology and the temporal variation in flow events (magnitude, frequency, timing, duration, rate of change) not only creates the spatial complexity of wetted habitat in these dryland rivers but also determines their temporal persistence (Kingsford et al. 1999). These wetlands act as hydrological 'sponges' absorbing water from upstream, filling and then releasing water to channels and wetlands further downstream.

A similar pattern of riverine wetland complexes can be found within the broader catchment of the Murray-Darling Basin, Australia. All the main tributaries of the Darling River have associated sponge-like wetlands in their lower reaches, which include the Gwydir Wetlands in the lower reaches of the Gwydir River, the Macquarie Marshes on the lower Macquarie River, the wetlands of the lower Balonne floodplain and Narran Lakes on the lower Condamine-Balonne, the lower Paroo Wetlands on the Paroo River, the Macintyre and Weir River wetland on the Border Rivers, and the Namoi River floodplain (Kingsford 2004). Further downstream on the Darling River itself, the Menindee Lakes, now a regulated water storage, acted historically as a large sponge-like wetland composed of a series of lakes of different flooding frequency, similar to the Coongie Lakes on the lower Cooper Creek in the Lake Eyre Basin (Puckridge et al. this issue). Tributaries of the River Murray also contain similar wetlands, including the Lowbidgee Wetlands on the Murrumbidgee River, Great Cumbung Swamp on the Lachlan River, and Hattah Lakes and Barmah-Millewa Forest on the River Murray itself (Fig. 3).

These complex riverine wetlands systems, situated within river catchments rather than restricted to river termini, are not exclusive to Australian dryland rivers. For example, the Tarim River in arid-zone China has a similarly diverse suite of wetland habitats (lakes, ponds and marshes) throughout its middle and lower reaches that provide habitat and refuge for many local and migratory species (Zhao et al. 2009). In other parts of the globe, many rivers also have complex wetland and/or floodplain features. Examples include the peat bog wetlands of rivers in northern temperate continents; the inland Delta of the Okavango River, the Hadejia-Nuguru wetlands of the Yobe-Komadugu Basin, and the wetland habitats of the Nile River in Africa; the Pantenal Wetlands of the Paraguay River in South America; and the Mesopotamian Marshlands of the Tigris and Euphrates Basins 
in the Middle East (e.g. Hamilton et al. 1997; Williams 1999; Richardson et a. 2005; Milzow et al. 2009). These wetlands are all likely to act as hydrological sponges within their respective river-floodplain networks, retaining water for varying durations before it can be released to the channels downstream (Davies et al. 1993).

\section{Sequential Flooding: the Link between Space and Time}

Sequential high flow events are essential for the ecological persistence of these sponge-like riverine wetlands within large river systems and for the transmission of flows further downstream through the channel network. Their benefit to aquatic ecosystems, in terms of productivity, was described by Puckridge et al. (2000) for a series of five floods that occurred over a four year period corresponding with positive values of the Southern Oscillation Index (SOI) (i.e. La Niña years, when rainfall and flooding tends to increase in Australia, see Philander 1990):

Areas inundated in the Coongie Lakes region in 1987-1991 increased each year, and there was more than an order of magnitude difference between 1987-1988 and 1989-1990. This reflected successive increases in flood magnitude and also the retention of water from prior floods. Thus, while the volume of the 1991 flood was $36 \%$ of that in 1989, its maximal extent (22 April 1991) was $64 \%$ of that in 1989 (7 July 1989) (Puckridge et al. 2000: 392-3).

In turn, these sequential floods had cumulative, positive effects on the reproductive output of four native fish species: Nematalosa erebi (Clupeidae), Hypseleotris klunzingeri (Eleotridae), Melanotaenia splendida tatei (Melanotaeniidae) and Retropinna semoni (Retropinnidae). Interestingly, the magnitude of the response in exotic Gambusia holbrooki (Poeciliidae) was reduced compared to that of the native species. This suggests that the native species possess a recruitment advantage over the exotic Gambusia during the serial floods (see Costelloe et al. this issue). These floods also had significant value for the support of waterbird communities (Kingsford and Porter 1993; Kingsford et al. 1999).

An analysis of SOI values and simulated, mean daily flow data (1924 - 2005) from gauging stations in the Darling River system under 'natural' conditions (before European settlement and river regulation) shows similar correlations between positive SOI values and increased flow magnitudes. In fact, an increasing amount of variation in total annual flow is explained by mean annual SOI values when discharge is cumulatively combined from upstream gauges and those further downstream (Macintyre River at Goondiwindi 
alone, $\mathrm{R}^{2}=0.21$; Goondiwindi + Barwon River at Mungindi, $\mathrm{R}^{2}=0.25$, Goondiwindi + Mungindi + Darling River at Bourke, $\mathrm{R}^{2}=0.26$; Goondiwindi + Mungindi + Bourke + Darling River at Wilcannia, $\mathrm{R}^{2}=0.30$ ) (Fig. 4). This amount of variation explained by the SOI (21-30\%) is typical of rivers throughout the world and supports the findings of Puckridge et al. (2000). In addition, the positive correlation between discharge at upstream gauging stations (from upstream to downstream: Goondiwindi, Mungindi and Bourke) and Wilcannia (most downstream) is increased when analysed cumulatively (Fig. 5). These relationships may seem obvious; however, they confirm the critical dependence of downstream aquatic habitats on upstream flows. For example, floodplain wetlands within the Murray-Darling Basin receive the majority of their fresh water inputs from their corresponding main channel during times of high flow (Maheshwari et al. 1995). In fact, the sustained biodiversity of both floodplain and terminal wetlands in this system, and their role as refugia during periods of low or high flow disturbance, relies on flows delivered from upstream channels (Kingsford 2000).

Further to this, we believe that a sequence of flow events is necessary to sustain functional river ecosystems in arid environments. Cooper Creek in Australia’s Lake Eyre Basin experienced a large flood event in March 2000, covering nearly $14000 \mathrm{~km}^{2}$ (Bunn et al. 2006). Prior to this, the last major flood occurred in 1990. However, there was a sequence of three flow events in upland reaches (in the Darr, Thomson, Alice and Barcoo Rivers) leading up to the 2000 flood event in the lower Cooper Creek (Fig. 6). Although there was a longitudinal reduction in total discharge from approximately $980000 \mathrm{ML}$ at Thomson River (Stonehenge gauge) to $360000 \mathrm{ML}$ at Cooper Creek (Cullyamurra guage), the sequential flood events still resulted in the transport of water down through the system. It is these events that we propose are necessary for the replenishment of riverine, floodplain and terminal wetlands. Indeed, the significant evaporation and transmission losses from northern parts of the Cooper Creek catchment (where most of the run-off is generated) to lowland reaches (Knighton and Nanson, 1994), where surface water replenishes alluvial groundwater via percolation through sandy beds, make these events and their wetting effect on wetlands vital for maintaining the biodiversity and ecological function of the whole river system.

Similar sequential flooding occurred in Cooper Creek in 2008, 2009 and now in 2010. In 2008, small flows within the Cooper caused minor flooding and filling of floodplain 
wetlands and channel systems; in 2009, further flows filled the riverine wetlands of the channel country, made their way to Coongie Lakes and then continued on to partially fill Lake Eyre (Fig. 3). Similar flooding was observed in the Georgina-Diamantina river system in the western part of the Lake Eyre Basin (in 2009). In 2010, the sequence now seems complete: another major rainfall event has again delivered water to all the major rivers of the Lake Eyre Basin, and with the riverine wetland 'sponges' already partially filled, the water will be able penetrate further, possibly filling the terminal Lake Eyre for the first time since 1990 .

\section{Breaking the Sequence and Preventing the Boom}

The amount of water received by the major wetlands of the Murray-Darling Basin (e.g. Gwydir wetlands, Macquarie Marshes, Barmah-Millewa Forest and Moira Marshes, Menindee Lakes and Chowilla floodplain; Fig. 3) has declined considerably since the advent of water resource development (Kingsford and Thomas 1995; 2004); a phenomenon observed in or predicted for many river systems throughout the world (see Zhao et al. 2009; Larned et al. 2010). In the Murray-Darling Basin, dams, diversions and river management have diminished flooding to the wetlands, changing their ecology and resulting in the death, or poor health, of aquatic biota (Kingsford 2000; Reid and Brooks 2000; Kingsford et al. 2004). If these wetlands are acting as 'sponges' that must fill before water can be released and move further downstream, the loss of sequential floods in this system suggests that the wetlands, particularly those further downstream, have little chance of being replenished with flood waters.

To demonstrate, we use a hypothetical series of drought and flood years to compare the hydrological effects of sequential flooding on the major tributaries, rivers and wetlands of the Murray-Darling Basin under a natural flow regime and a water resource development scenario (Fig. 7). A five year sequence comprised of drought, three floods and drought under natural (anthropogenically unmodified) flow conditions fills the wetland 'sponges' progressively from uplands to lowlands. This culminates in major flooding of rivers and wetlands in the third flood year, followed by a year of receding in-channel water levels but sustained aquatic habitat in the wetland refugia. In contrast, the same sequence of drought and floods under the water resource development scenario, where water is extracted from the upstream river supply in each of the flood years, provides a noticeably different outcome. If upland wetlands are filled during the first flood year but water is removed such 
that downstream reaches are not wetted, the lower wetlands will not fill during the second flood year, unless of course local rainfall generates an exceptionally large flood. If water is continually removed from upland wetlands, consecutive flood events may be of little benefit to lowland habitats and major flooding of the lowland wetland system is unlikely to occur.

For regulated dryland rivers such as the Murray-Darling, an environmental flow plan could be developed that would allow for sequential flooding to be re-instated so that the wetland sponges could be replenished and water transferred down the system for ecosystem and biodiversity outcomes. Such a plan would allow for a scaled, proportional removal of water, depending on the river system in question (sensu Arthington et al. 2006) and at which point in the natural hydrological sequence the water is removed. For example, a small flood that occurs in the headwaters of a river may only allow for an appropriately small proportion of water to be removed, particularly if it was preceded by a dry period. This would allow a substantial amount of the floodwaters to wet the channel and wetland sediments in the system's upper reaches. A larger proportion of water could be removed from a subsequent flood event, but not so much that the wetlands and channels had little chance of being re-wetted. Using this scaled approach, the largest amount of water that could be removed would be proportional to the largest flood, occurring at the end of a series of (smaller) flood events.

However, if the sequence of wetland flooding is prevented and major flooding events are inhibited, the productivity booms typical of unregulated dryland rivers will be unlikely to eventuate. Indeed, evidence shows that when floodplains are left dry for long periods, postflood booms are diminished (Capon 2007; Jenkins and Boulton 2007). Many species rely on these booms; in unregulated Cooper Creek, native fish utilize the floodplain during periods of massive inundation, which provides an environment rich in both autochthonous and allochthonous food resources (e.g. Balcombe et al. 2005; Balcombe and Arthington 2009). Australian waterbirds also depend on these floodplain resources, moving en masse to productive habitat and breeding zones when flooding triggers production booms in fish, frogs, aquatic invertebrates and macrophytes (Kingsford et al. 1999; Kingsford et al. this issue). These events are of major importance to the persistence of assemblages in aquatic refugia and overall ecosystem function. 
Since 1857, thousands of weirs (3600 in the Murray-Darling Basin alone) and floodplain levee banks, 446 large dams (> $10 \mathrm{~m}$ crest height) and over 50 intra- and inter-basin water transfer schemes have been implemented to secure water for human consumption within Australia (Arthington and Pusey 2003). Much of the water stored by large dams is diverted upstream of floodplain wetlands, and the majority of floodplain wetlands on developed rivers may no longer flood (Kingsford 2000). For the Murray-Darling Basin, the sequence of flooding has been severely disrupted. In fact, the Coorong, Lower Lakes and Murray Mouth wetland system, listed as a Wetland of International Significance under the Ramsar Convention, now receives so little input of freshwater that restoration may require environmental flow releases of at least 500 gigalitres from upstream barrages during dry periods (Brookes et al. 2009).

This drying of wetlands due to water abstraction and diversion is not unique to the Murray-Darling Basin. Dramatic ecological impacts and fish losses have been observed in many regulated dryland floodplain rivers, for example, the Aral Sea in Uzebekistan and Kazakhstan, the Mesopotamian Marshes in Iran and Lake Mono in California, USA (Kingsford et al. 2006). A recent study of wetlands in the Tarim River in arid-zone China (Zhao et al. 2009) demonstrates the adverse effects that dams and irrigation practices can have on dryland river biodiversity, as mediated through the loss of flood sequences and the parching of wetland 'sponges'. The area covered by wetlands in this system, particularly off-channel lakes and marshes upon which migratory bird species depend, has dwindled substantially in the last several decades, along with a decline in freshwater and rivermargin biodiversity. For example, a dam constructed across the river's lower reaches in 1972 resulted in the drying of a 321-km stretch of river below the dam wall (Chen et al. 2006) and a 3-12-m decline in groundwater levels, subsequently shrinking the area covered by riparian wetlands. Thus, our sequential flooding concept, and that of wetland ‘sponges', apparently has a ubiquitous application to dryland river systems worldwide.

\section{Conclusions}

We propose that sequential high flow events that generate significant flooding and progressively fill the wetland 'sponges' of arid landscapes are essential for the ecological persistence of wetland habitats within dryland river systems. These flood sequences drive booms in the productivity that sustain aquatic and terrestrial biota over large spatial and temporal scales and subsidise assemblages in isolated aquatic habitats during dry periods. 
By artificially removing water from upland wetlands or in-channel flows, water from flood events will not saturate the sponges and move down the system to wet downstream sediments. As a result, the benefits of sequential flooding to downstream wetlands and their biotic communities will be greatly reduced or lost completely.

\section{Acknowledgements}

Queensland flow data for the Cooper Creek river system were provided to Catherine Leigh by the State of Queensland (Department of Natural Resources, Mines and Water) in 2006. Flow data for Cooper Creek at Cullyamurra were provided by the South Australian Department of Land, Water and Biodiversity Conservation in 2010 and are available online at http://e-nrims.dwlbc.sa.gov.au/swa/ (verified 9 March 2010). Integrated Quantity and Quality Model (IQQM) flow data for the Murray Darling Basin were provided to Fran Sheldon by the New South Wales Department of Land and Water Resources in 1995. Doug Ward provided the Lake Eyre and Murray Darling Basin illustrations in Figure 3. We thank two anonymous reviewers for their comments on our manuscript.

\section{References}

Arthington, A. H. and Pusey, B. J. (2003). Flow restoration and protection in Australian rivers. River Research and Applications 19, 377-395.

Arthington, A. H., Balcombe, S. R., Wilson, G. A., Thoms, M. C. and Marshall, J. (2005). Spatial and temporal variation in fish-assemblage structure in isolated waterholes during the 2001 dry season of an arid-zone floodplain river, Cooper Creek, Australia. Marine and Freshwater Research 56, 25-35.

Arthington, A. H., Bunn, S. E., Poff, N. L. and Naiman, R. J. (2006). The challenge of providing environmental flow rules to sustain river ecosystems. Ecological Applications 16, 1311-1318.

Arthington, A. H., Olden, J. D., Balcombe, S. R. and Thoms, M. C. (this issue). Multi-scale environmental factors explain fish losses and refuge quality in drying waterholes of Cooper Creek, an Australian arid-zone river. Marine and Freshwater Research. 
Balcombe, S. R. and Arthington, A. H. (2009). Temporal changes in fish abundance in response to hydrological variability in a dryland floodplain river. Marine and Freshwater Research 60, 146-159.

Balcombe, S. R., Arthington, A. H., Foster, N. D., Thoms, M. C., Wilson, G. A., et al. (2006). Fish assemblages of an Australian dryland river: abundance, assemblage structure and recruitment patterns in the Warrego River, Murray-Darling Basin. Marine and Freshwater Research 57, 619-633.

Balcombe, S. R., Bunn, S. E., McKenzie-Smith, F. J. and Davies, P. E. (2005). Variability of fish diets between dry and flood periods in an arid zone floodplain river. Journal of Fish Biology 67, 1552-1567.

Balcombe, S. R., Bunn, S. E., Arthington, A. H., Fawcett, J. H., McKenzie-Smith, F. J. et al. (2007). Fish larvae, growth and biomass relationships in an Australian arid zone river: links between floodplains and waterholes. Freshwater Biology 52, 2385-2398.

Bayley, P. B. (1991). The flood pulse advantage and the restoration of river-floodplain systems. Regulated Rivers: Research and Management 6, 75-86.

Bond, N. R., Lake, P. S. and Arthington, A. H. (2008). The impact of drought on freshwater ecosystems: an Australian perspective. Hydrobiologia 600, 3-16.

Bridgewater, P. B. (1987). The present Australian environment - terrestrial and freshwater. In: Fauna of Australia Volume 1A General Articles. (Eds G. R. Gyne and D. W. Walton), pp. 69-100. (Australian Government Printing Service: Canberra, Australia)

Brookes, J. D., Lamontagne, S., Aldridge, K. T., Benger, S., Bissett, A., et al. (2009). Ecosystem assessment framework to guide management of the Coorong. Final report of the CLLAMM Ecology Research Cluster. (CSIRO: Water for a Healthy Country National Research Flagship: Canberra, Australia)

Bunn, S. E., Davies, P. M. and Winning, M. (2003). Sources of organic carbon supporting the food web of an arid zone floodplain river. Freshwater Biology 48, 619-635. 
Bunn, S. E., Thoms, M. C., Hamilton, S. K. and Capon, S. J. (2006). Flow variability in dryland rivers: boom, bust and the bits in between. River Research and Applications 22, 179-186.

Burford, M. A., Cook, A. J., Fellows, C. S., Balcombe, S. R. and Bunn, S. E. (2008). Sources of carbon fuelling production in an arid floodplain river. Marine and Freshwater Research 59, 224-234.

Capon, S. J. (2005). Flood variability and spatial variation in plant community composition and structure on a large arid floodplain. Journal of Arid Environments 60, 283-302.

Capon, S. J. (2007). Effects of flooding on seedling emergence from the soil seed bank of a large desert floodplain. Wetlands 27, 904-914.

Chen YN, Takeuchi K, Xu CC, Chen YP, Xu ZX (2006a) Regional climate change and its effects on river runoff in the Tarim Basin, China. Hydrological processes 20, 2207-2216.

Chiew, F. H. S., Piechota, T. C., Dracup, J. A. and McMahon, T. A. (1998). El Niño/Southern Oscillation and Australian rainfall, streamflow and drought: links and potential forecasting. Journal of Hydrology 204, 138-149.

Costelloe, J. F., Reid, J. R. W., Pritchard, J. C., Puckridge, J. T., Bailey, V. E., et al. (this issue). Are alien fish disadvantaged by extremely variable flow regimes in arid zone rivers? Marine and Freshwater Research.

Davies, B. R., O’Keeffe, J. H. and Snaddon, C. D. (1993). A synthesis of the ecological functions, conservation and management of South African river ecosystems. (Water Research Commission: Pretoria, South Africa)

Dodds, W. K., Gido, K., Whiles, M. R., Fritz, K. M. and Matthews, W. J. (2004). Life on the edge: the ecology of Great Plains prairie streams. Bioscience 54, 205-216.

Fellows, C. S., Bunn, S. E., Sheldon, F. and Beard, N. J. (2009). Benthic metabolism in two turbid dryland rivers. Freshwater Biology 54, 236-253.

Finlayson, B. L. and McMahon, T. A. (1988). Australia v. the world: a comparative analysis of streamflow characteristics. In: Fluvial Geomorphology of Australia. (Ed. R. F. Warner), pp. 17-40. (Academic Press: Sydney, Australia) 
Fisher, S. G., Gray, L. J., Grimm, N. B. and Busch, D. E. (1982). Temporal succession in a desert stream ecosystem following flash flooding. Ecological Monographs 52, 93-110.

Gallardo, B., Gascon, S., Gonzalez-Sanchis, M., Cabezas, A. and Comin, F. A. (2009). Modelling the response of floodplain aquatic assemblages across the lateral hydrological connectivity gradient. Marine and Freshwater Research 60, 924-935.

Gibling, M. R., Nanson, G. C. and Maroulis, J. C. (1998). Anastomosing river sedimentation in the Channel Country of central Australia. Sedimentology 45, 595-619.

Heffernan, J. B. (2008). Wetlands as an alternative stable state in desert streams. Ecology 89, 1261-1271.

Hamilton, S. K., Bunn, S. E., Thoms, M. C. and Marshall, J. C. (2005). Persistence of aquatic refugia between flow pulses in a dryland river system (Cooper Creek, Australia). Limnology and Oceanography 50, 743-754.

Hamilton, S. K., Sippel, S. J., Calheiros, D. F. and Melack, J. M. (1997). An anoxic event and other biogeochemical effects of the Pantanal wetland on the Paraguay River. Limnology and Oceanography 42, 257-272.

Hughes, D. A. (2005). Hydrological issues associated with the determination of environmental water requirements of ephemeral rivers. River Research and Applications 21, 899-908.

Humphries, P., King, A. J. and Koehn, J. D. (1999). Fish, flows and flood plains: links between freshwater fishes and their environment in the Murray-Darling river system, Australia. Environmental Biology of Fishes 56, 129-151.

Jacobson, P. J., Jacobson, K. M., Angermeier, P.L. and Cherry, D. S. (2000). Variation in material transport and water chemistry along a large ephemeral river in the Namib Desert. Freshwater Biology 44: 481-491.

Jenkins, K. M. and Boulton, A. J. (2007). Detecting impacts and setting restoration targets in arid-zone rivers: aquatic microinvertebrate responses to floodplain inundation. Journal of Applied Ecology 44: 823-832. 
Junk, W. J. and Wantzen, K. M. (2003). The flood pulse concept: new aspects, approaches and applications - an update. In: The Second International Symposium on the Management of Large Rivers for Fisheries: Sustaining Livelihoods and Biodiversity in the New Millennium. (Eds R. L. Welcomme and T. Petr), pp. 117-140. (Food and Agriculture Organisation of the United Nations \& Mekong River Commission: Phnom Penh, Cambodia)

Junk, W. J., Bayley, P. B. and Sparks, R. E. (1989). The flood pulse concept in riverfloodplain systems. Special Publication of the Canadian Journal of Fisheries and Aquatic Sciences 106, 110-127.

Kennard, M. J., Pusey, B. J., Olden, J. D., Mackay, S. J., Stein, J. L. et al. (2010). Classification of natural flow regimes in Australia to support environmental flow management. Freshwater Biology 55, 171-193.

Kingsford, R. T. (2000). Ecological impacts of dams, water diversions and river management on floodplain wetlands in Australia. Austral Ecology 25, 109-127.

Kingsford, R. T. (2004). Waterbirds and wetlands of the Darling River: 'a wide river with pelicans and other waterfowl' (Sturt 1829). In: The Darling (Ed. R. Breckwoldt), pp. 234259. (Murray-Darling Basin Commission: Canberra, Australia)

Kingsford, R. T. and Porter, J. L. (1993). Waterbirds of Lake Eyre. Biological Conservation 65, 147-157.

Kingsford, R. T. and Thomas, R. F. (1995). The Macquarie Marshes in arid Australia and their waterbirds: a 50 year history of decline. Environmental Management 19, 867-878.

Kingsford, R.T. and Thomas, R. F. (2004). Destruction of wetlands and waterbird populations by dams and irrigation on the Murrumbidgee River in arid Australia. Environmental Management 34, 383-396.

Kingsford, R. T., Curtin, A. L. and Porter, J. (1999). Water flows on Cooper Creek in arid Australia determine 'boom' and 'bust' periods for waterbirds. Biological Conservation 88, 231-248. 
Kingsford, R. T., Jenkins, K. M. and Porter, J. L. (2004). Imposed hydrological stability on lakes in arid Australia and effect on waterbirds. Ecology 85, 2478-2492.

Kingsford, R. T., Lemly, A. D. and Thompson, J. R. (2006). Impacts of dams, river management and diversions on desert rivers. In: Ecology of Desert Rivers. (Ed. R. T. Kingsford), pp. 336-345 (Cambridge University Press: Melbourne, Australia)

Kingsford, R. T., Roshier, D. A., and Porter, J. L. (this issue). Australian waterbirds - time and space travellers in dynamic desert landscapes. Marine and Freshwater Research.

Knighton, A. D. and Nanson, G. C. (1994). Waterholes and their significance in the anastomosing channel system of the Cooper Creek, Australia. Geomorphology 9, 311-324.

Knighton, A. D. and Nanson, G. (1997). Distinctiveness, diversity and uniqueness in arid zone river systems. In: Arid Zone Geomorphology: Process, Form and Change in Drylands. (Ed. D. Thomas), pp. 185-203. (John Wiley \& Sons Ltd: Chichester, UK)

Lake, P.S. (1995). Of floods and droughts: river and stream ecosystems of Australia. In: River and Stream Ecosystems. (Eds C. E. Cushing, K. W. Cummins and G. W. Minshall), pp. 659-694. (Elsevier: Amsterdam, The Netherlands)

Lake, P.S. (2003). Ecological effects of perturbation by drought in flowing waters. Freshwater Biology 48, 1161-1172.

Larned, S. T., Datry, T., Arscott, D. B. and Tockner, K. (2010). Emerging concepts in temporary-river ecology. Freshwater Biology 55, 717-738.

Leigh, C. and Sheldon, F. (2008). Hydrological changes and ecological impacts associated with water resource development in large floodplain rivers in the Australian tropics. River Research and Applications 24, 1251-1270.

Leigh, C. and Sheldon, F. (2009). Hydrological connectivity drives patterns of macroinvertebrate biodiversity in floodplain rivers of the Australian wet /dry tropics. Freshwater Biology 54, 549-571.

Maheshwari, B. L., Walker, K. F. and McMahon, T. A. (1995). Effects of regulation on the flow regime of the River Murray, Australia. Regulated Rivers: Research and Management 10, $15-38$. 
Mallen-Cooper, M. and Stuart, I. G. (2003). Age, growth and non-flood recruitment of two potamodromous fishes in a large semi-arid/ temperate river system. River Research and Applications 19, 697-719.

Malmqvist, B. (2002). Aquatic invertebrates in riverine landscapes. Freshwater Biology 47, 679-694.

Maltchik, L., Medeiros, E. S. F. (2006). Conservation importance of semi-arid streams in north-eastern Brazil: implications of hydrological disturbance and species diversity. Aquatic Conservation: Marine and Freshwater Ecosystems 16, 665-677.

Marshall, J. C., Sheldon, F., Thoms, M. and Choy, S. (2006). The macroinvertebrate fauna of an Australian dryland river: spatial and temporal patterns and environmental relationships. Marine and Freshwater Research 57, 61-74.

Milzow, C., Kgotlhang, L., Bauer-Gottwein, P., Meier, P. and Kinzelbach, W. (2009). Regional review: the hydrology of the Okavango Delta, Botswana-processes, data and modelling. Hydrogeology Journal 17, 1297-1328.

Monk, W. A., Wood, P. J., Hannah, D. M. and Wilson, D. A. (2007). Selection of river flow indices for the assessment of hydroecological change. River Research and Applications 23, 113-122.

Naiman, R. J., Latterell, J. J., Pettit, N. E. and Olden, J. D. (2008). Flow variability and the biophysical vitality of river systems. Comptes Rendus Geoscience 340, 629-643.

Noe, G. B. and Hupp, C. R. (2007). Seasonal variation in nutrient retention during inundation of a short-hydroperiod floodplain. River Research and Applications 23, 10881101.

Olden, J. D. and Poff, N. L. (2003). Redundancy and the choice of hydrologic indices for characterizing streamflow regimes. River Research and Applications 19, 101-121.

Paillex, A., Dolédec, S., Castella, E. and Mérigoux, S. (2009). Large river floodplain restoration: predicting species richness and trait responses to the restoration of hydrological connectivity. Journal of Applied Ecology 46, 250-258. 
Pettit, N. and Naiman, R. (2005). Flood-deposited wood debris and its contribution to heterogeneity and regeneration in a semi-arid riparian landscape. Oecologia 145, 434-444.

Pettit, N. E., Froend, R. H. and Davies, P. M. (2001). Identifying the natural flow regime and the relationship with riparian vegetation for two contrasting Western Australian rivers. Regulated Rivers: Research and Management 17, 201-215.

Philander, S. G. (1990). El Niño, La Niña and the Southern Oscillation. (Academic Press: San Diego)

Poff, N. L., Allan, J. D., Bain, M. B., Karr, J. R., Prestegaard, K. L., et al. (1997). The natural flow regime: a paradigm for river conservation and restoration. Bioscience 47, 769784.

Poff, N. L., Olden, J. D., Merritt, D. M. and Pepin, D. M. (2007). Homogenization of regional river dynamics by dams and global biodiversity implications. Proceedings of the National Academy of Sciences of the United States of America 104, 5732-5737.

Puckridge, J. T., Costelloe, J. F., and Reid, J. R. W. (this issue). Ecological responses to variable water regimes in arid zone wetlands: Coongie Lakes, Australia. Marine and Freshwater Research.

Puckridge, J. T., Costelloe, J. F. and Walker, K. F. (1998b). DRY/WET: Effects of changed water regime on the fauna of arid zone wetlands (CD-ROM model and documentation). Report to the National Wetlands Research and Development Program. (Environment Australia and Land and Water Resources Research and Development Corporation: Australia)

Puckridge, J. T., Sheldon, F., Walker, K. F. and Boulton, A. J. (1998a). Flow variability and the ecology of large rivers. Marine and Freshwater Research 49, 55-72.

Puckridge, J. T., Walker, K. F. and Costelloe, J. F. (2000). Hydrological persistence and the ecology of dryland rivers. Regulated Rivers: Research and Management 16, 385-402.

Reid, M. A. and Brooks, J. J. (2000). Detecting effects of environmental water allocations in wetlands of the Murray-Darling Basin, Australia. Regulated Rivers: Research and Management 16, 479-496. 
Richardson, C. J., Reiss, P., Hussain, N. A., Alwash, A.J. and Pool, D. J. (2005). The restoration potential of the Mesopotamian marshes of Iraq. Science 307, 1307-1311.

Sheldon, F., and Fellows, C. S. (this issue). Water quality and water chemistry in two Australian dryland rivers: spatial and temporal variability and the role of flow. Marine and Freshwater Research.

Sheldon, F. and Puckridge, J. T. (1998). Macroinvertebrate assemblages of Goyder Lagoon, Diamantina River, South Australia. Transactions of the Royal Society of South Australia 122, 17-31.

Sheldon, F. and Thoms, M. C. (2006). Relationships between flow variability and macroinvertebrate assemblage composition: data from four Australian dryland rivers. River Research and Applications 22, 219-238.

Sheldon, F., Boulton, A. J. and Puckridge, J. T. (2002). Conservation value of variable connectivity: aquatic invertebrate assemblages of channel and floodplain habitats of a central Australian arid-zone river, Cooper Creek. Biological Conservation 103, 13-31. Sheldon, F., Bunn, S. E., Hughes, J. M., Arthington, A. H., Balcombe, S. R. et al. (this issue). Ecological roles and threats to aquatic refugia in arid landscapes: dryland river waterholes. Marine and Freshwater Research.

Simpson, H. A., Cane, M. A., Herczeg, A. L., Zebiak, S. E. and Simpson, J. H. (1993). Annual river discharges in southeastern Australia related to El Niño Southern Oscillation forecasts of sea surface temperatures. Water Resources Research 29, 3671-3680.

Stanley, E. H., Fisher, S. G. and Grimm, N. B. (1997). Ecosystem expansion and contraction in streams. Bioscience 47, 427-435.

Thoms, M. C. (2003). Floodplain-river ecosystems: lateral connections and the implications of human interference. Geomorphology 56, 335-349.

Thoms, M. C., Southwell, M. and McGinness, H. M. (2005). Floodplain-river ecosystems: fragmentation and water resources development. Geomorphology 71, 126-138.

Tockner, K., Malard, F., Ward, J. V. (2000). An extension of the flood pulse concept. Hydrological Processes 14, 2681-2883. 
Tockner, K., Pennetzdorfer, D., Reiner, N., Schiemer, F. and Ward, J. V. (1999).

Hydrological connectivity, and the exchange of organic matter and nutrients in a dynamic river-floodplain system (Danube, Austria). Freshwater Biology 41, 521-535.

Valett, H. M., Baker, M. A., Morrice, J. A., Crawford, C. S., Molles, M. C., et al. (2005). Biogeochemical and metabolic responses to the flood pulse in a semiarid floodplain. Ecology 86, 220-234.

Walker, K. F., Puckridge, J. T. and Blanch, S. J. (1997). Irrigation development on Cooper Creek, central Australia: prospects for a regulated economy in a boom-and-bust ecology. Aquatic Conservation: Marine and Freshwater Ecosystems 7, 63-73.

Walker, K. F., Sheldon, F. and Puckridge, J. T. (1995). A perspective on dryland river ecosystems. Regulated Rivers: Research and Management 11, 85-104.

700 Ward, J. V., Tockner, K. and Schiemer, F. (1999). Biodiversity of floodplain river ecosystems: ecotones and connectivity. Regulated Rivers: Research and Management 15, 125-139.

Welcomme, R. L., Bene, C., Brown, C. A., Arthington, A., Patrick Dugan, P., et al. (2006). Predicting the water requirements of river fisheries. In: Wetlands and Natural Resource Management. (Eds J. T. A. Verhoeven, B. Beltman, R. Bobbink and D. F. Whigham), pp. 123-154. (Springer-Verlag: Berlin, Germany)

Williams, W.D. (1999). Conservation of wetlands in drylands: a key global issue. Aquatic Conservation: Marine and Freshwater Ecosystems 9, 517-522.

Zhao, R., Chen, Y., Zhou, H., Li, Y., Qian, Y. et al. (2009). Assessment of wetland 710 fragmentation in the Tarim River basin, western China. Environmental Geology 57, 455464. 


\section{Figure captions}

Figure 1: Flow drives river function across a range of temporal and spatial scales, interacting with landscape and local environment characteristics to affect local assemblage characteristics, water quality and ecosystem processes.

Figure 2: Various features of the (a) flood pulse, (b) flow history and (c) flow regime that have ecological significance, modified from Walker et al. (1995).

Figure 3: Maps of (a) Lake Eyre and (b) Murray Darling Basins in Australia, showing their river systems and major wetland complexes.

Figure 4: Correlation between mean annual values of the Southern Oscillation Index (SOI) and simulated, total annual discharge ( $\mathrm{ML} \mathrm{y}^{-1}, \log (\mathrm{x}+1)$ transformed) in the Darling River system under conditions of pre-European settlement (1924 - 2005), cumulatively combined from upstream gauges to those further downstream (Goondiwindi, Goondiwindi + Mungindi, Goondiwindi + Mungindi + Bourke, Goondiwindi + Mungindi + Bourke + Wilcannia).

Figure 5: Cumulative, positive correlations between total annual discharge ( $\left.\mathrm{ML} \mathrm{y}^{-1}\right)$ at upstream gauging stations (from upstream to downstream: Goondiwindi, Mungindi and Bourke) and Wilcannia gauging station (most downstream) in the Darling River system 1924 - 2005, simulated for pre-European settlement conditions.

Figure 6: Sequential flooding in Cooper Creek river system: a sequence of three flow events (dark arrows), following a large flood event c. 1990, in the period leading up to the c. 2000 flood event in Cooper Creek. From top to bottom, hydrographs of total annual discharge (105 $\mathrm{ML} \mathrm{y}^{-1}$ ) are shown for upland (Darr River at Darr and Thomson River at Longreach), mid (Thomson River at Stonehenge; 1994 to 1999 data are missing) and lowland gauging stations (Cooper Creek at Cullyamurra). Schematic of river system depicts relative position of gauging stations in the network and is not to scale.

Figure 7: Sequential flooding: conceptual diagram for major tributaries, rivers and wetlands of a large river system (e.g. Murray Darling Basin). In the left panel, from top to bottom, a five year sequence of a dry year, three floods and another dry year is depicted 
under natural (anthropogenically unmodified) flow conditions, where floodplain and terminal wetlands (closed circles) are progressively filled from uplands to lowlands (thick lines). This culminates in major flooding of rivers and wetlands in the third flood year, followed by a year of receding in-channel water levels but sustained aquatic habitat in the wetland refugia. This is contrasted with the same sequence under an irrigation scenario: upland wetlands are filled during the first flood year, but water is removed for irrigation (closed rectangles) so that lower wetlands do not fill and major flooding of the system does not eventuate, even after three consecutive years of upland flooding. 


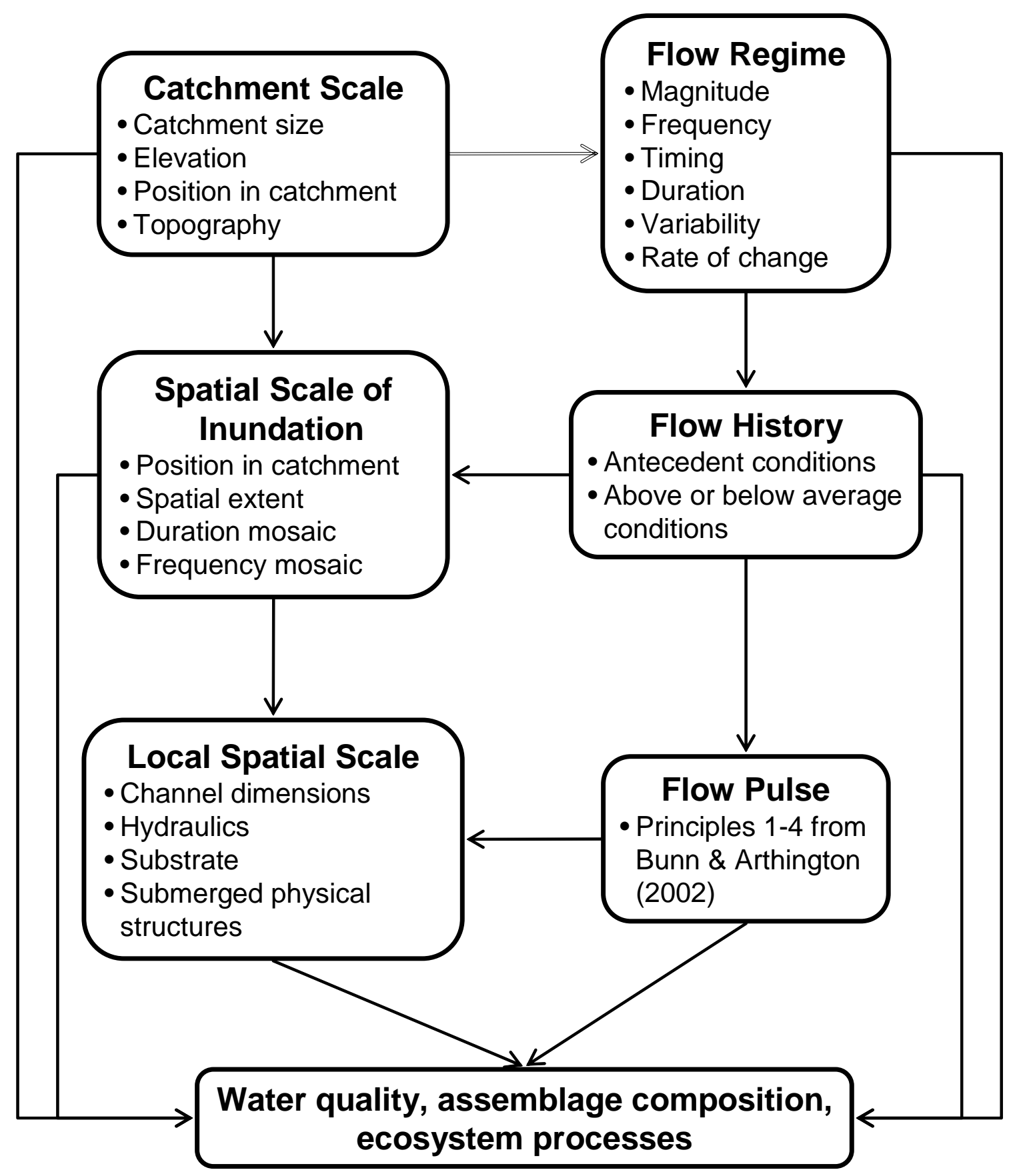

Figure 1 


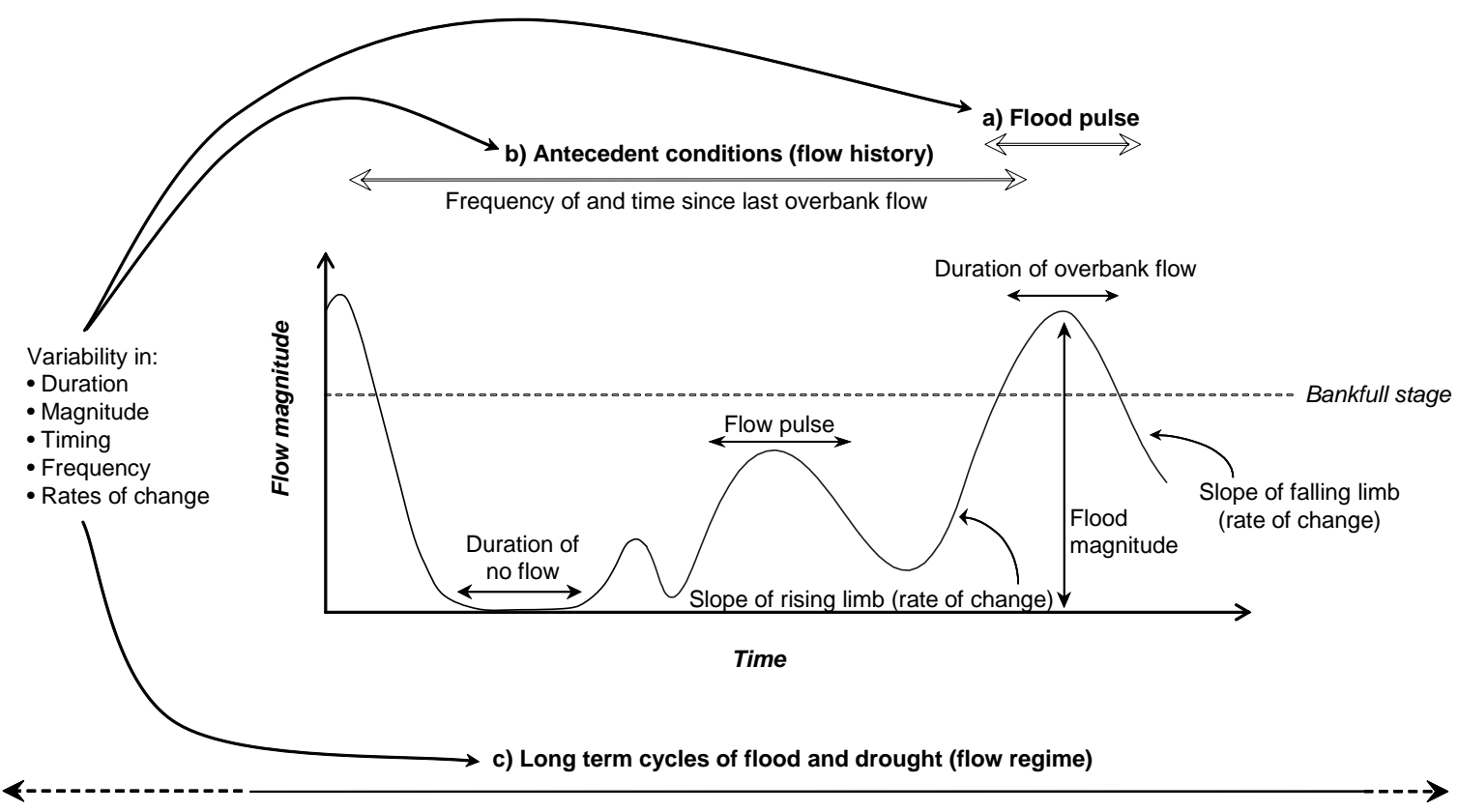

Figure 2 


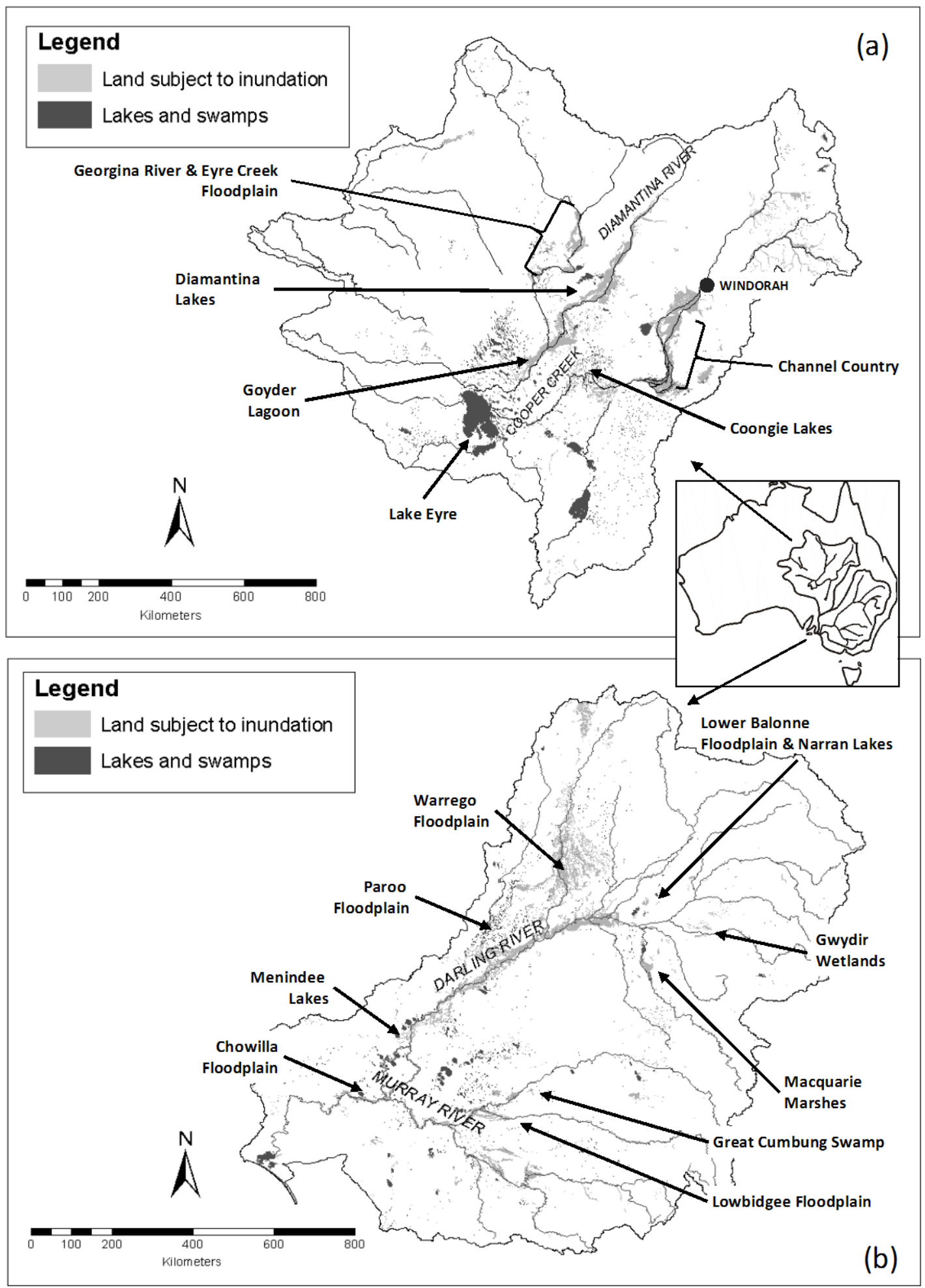

Figure 3 


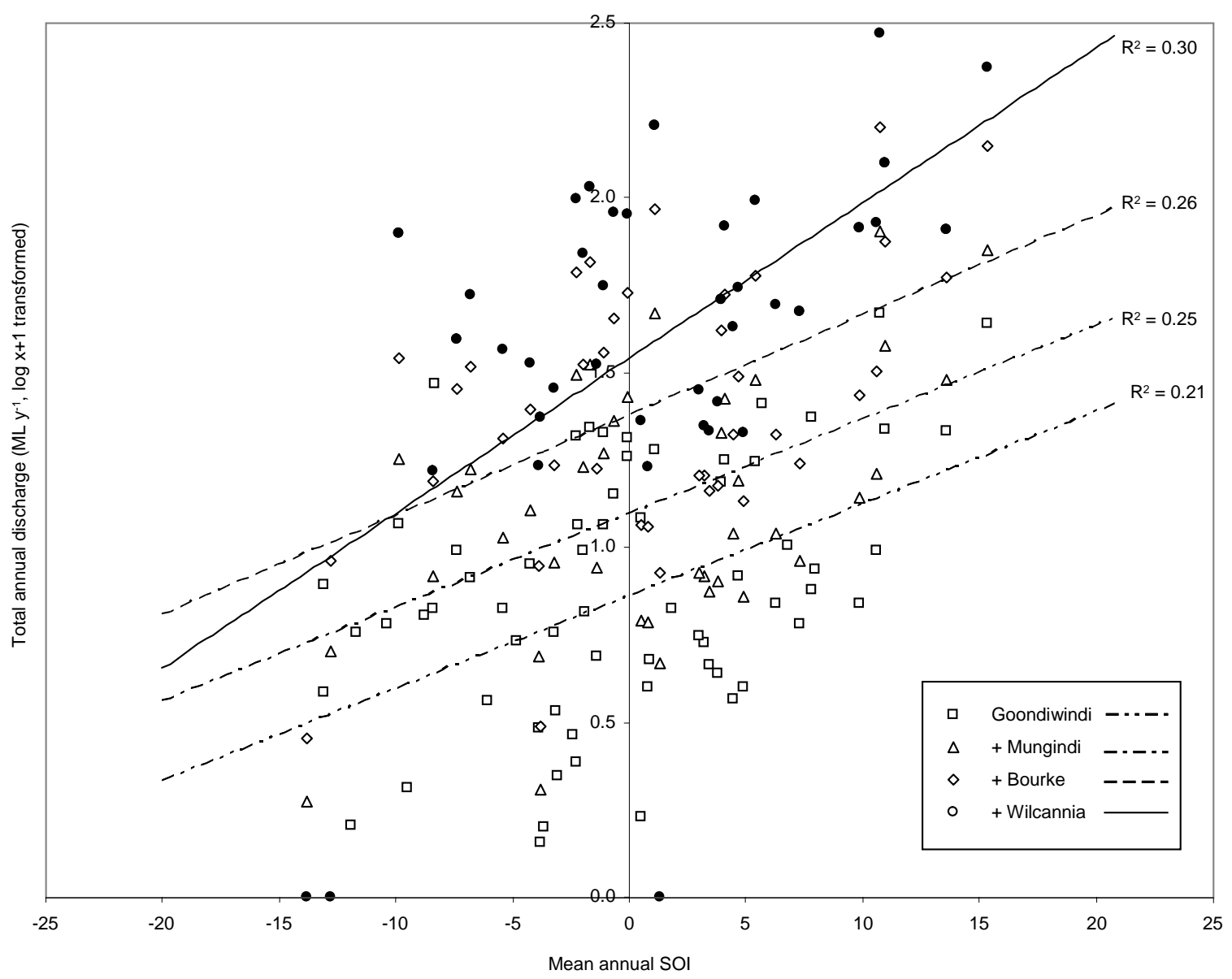

Figure 4 

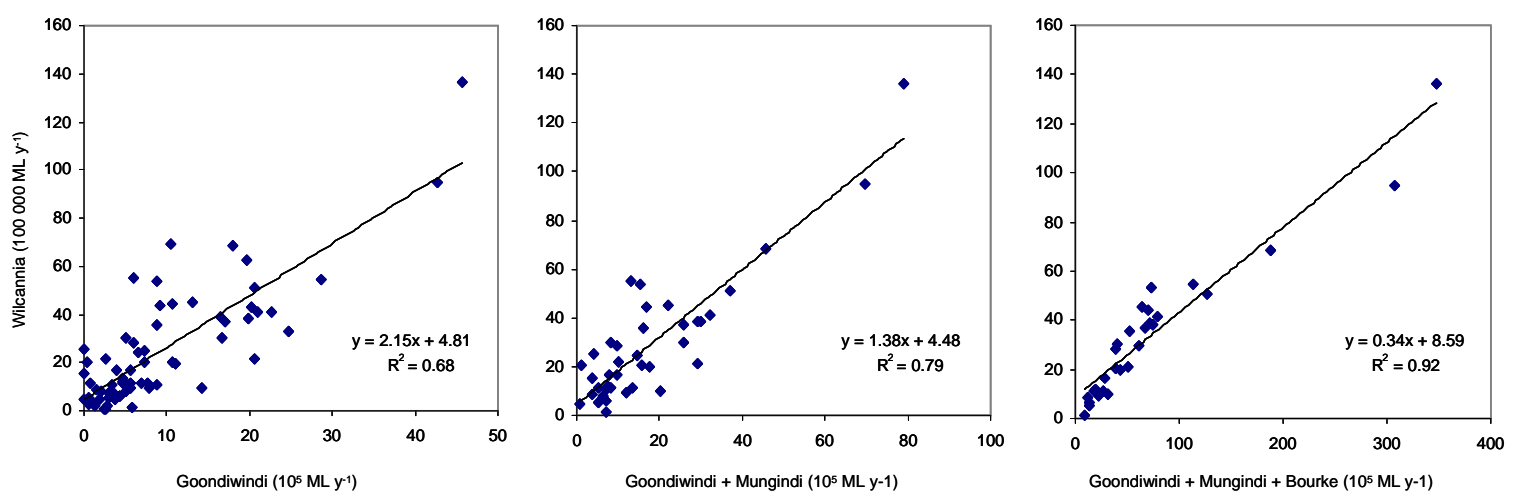

$770 \quad$ Figure 5 

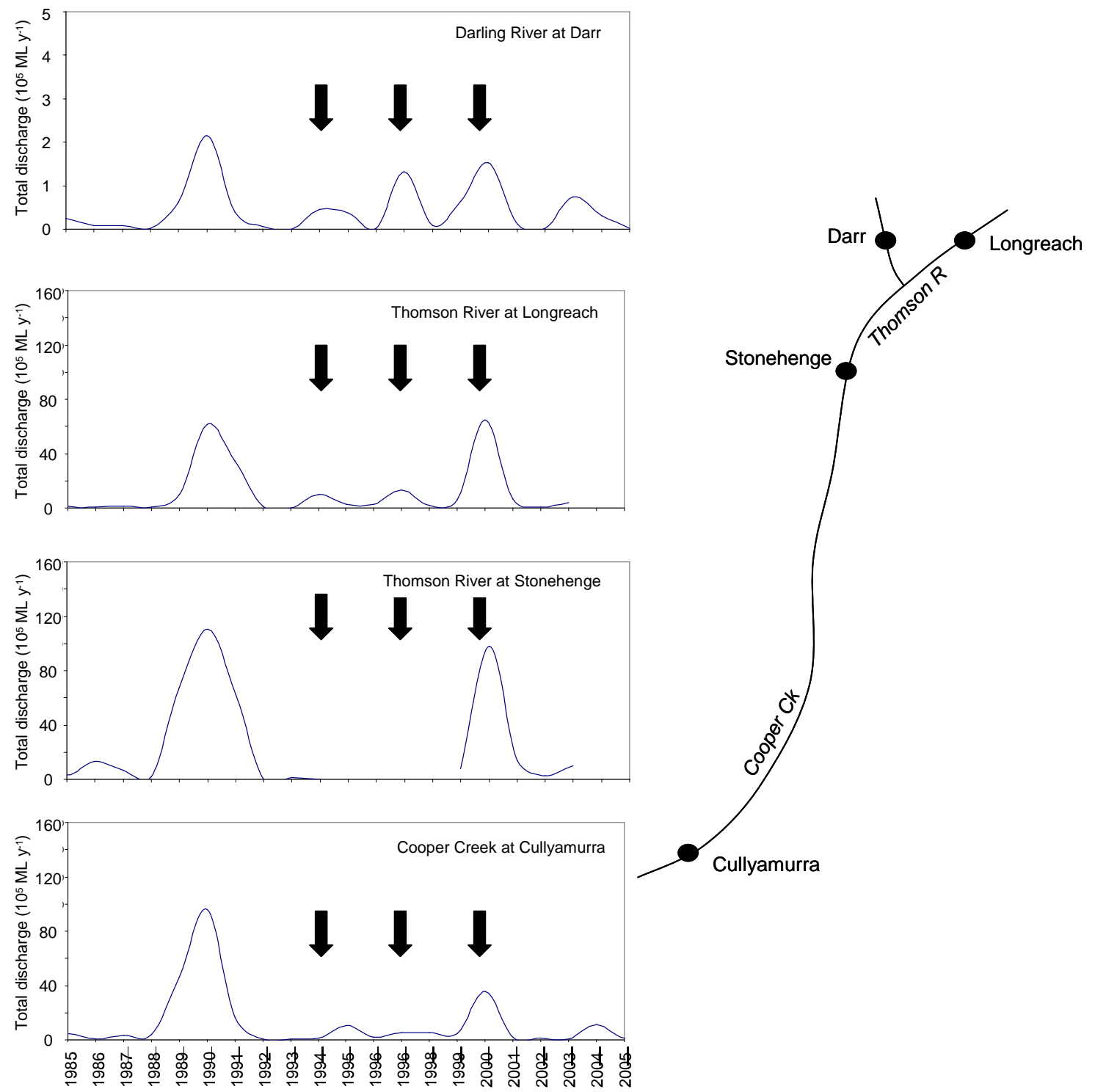

Cullyamurra

Figure 6 
Flood sequence under the natural flow regime
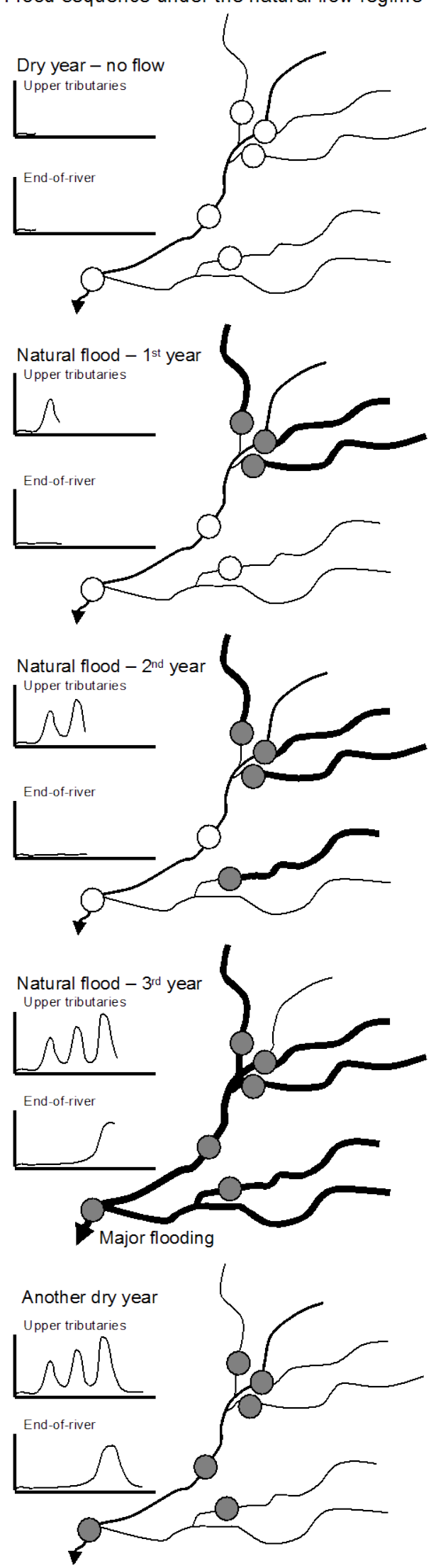

Flood sequence under anthropogenic alteration
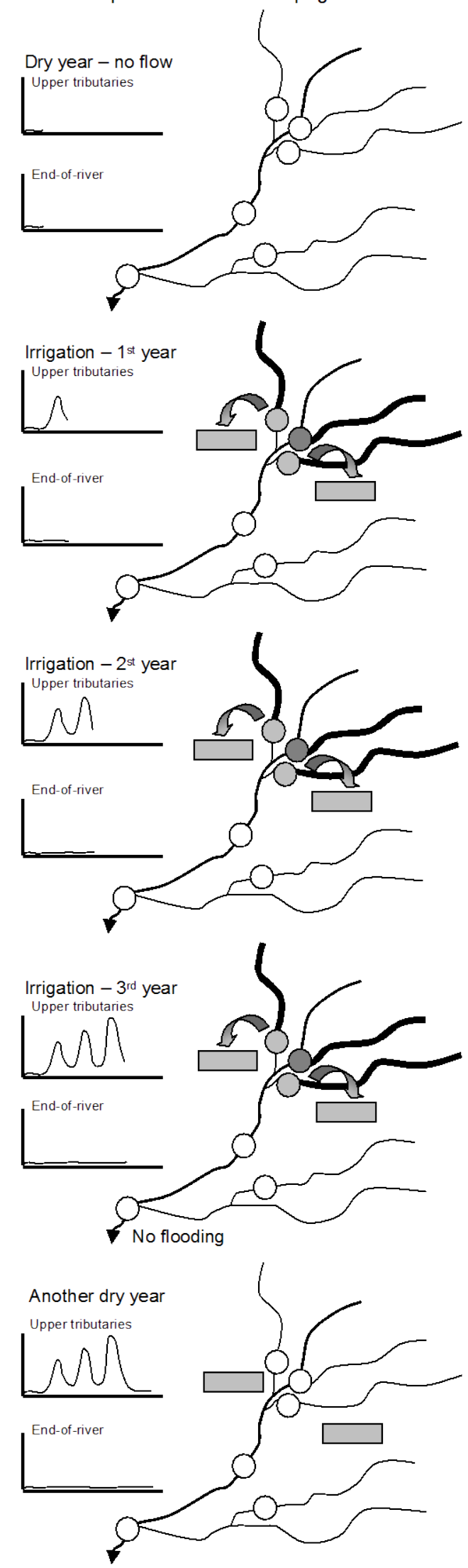

Figure 7 